\title{
Mixed Feedstock Approach to Lignocellulosic Ethanol Production-Prospects and Limitations
}

\author{
Mushafau Adebayo Oke ${ }^{1,2} \cdot$ Mohamad Suffian Mohamad Annuar ${ }^{1} \cdot$ Khanom Simarani $^{1}$
}

Published online: 17 June 2016

(C) The Author(s) 2016. This article is published with open access at Springerlink.com

\begin{abstract}
Lignocellulosic ethanol is a promising alternative to fossil-derived fuels because lignocellulosic biomass is abundant, cheap and its use is environmentally friendly. However, the high costs of feedstock supply and the expensive processing requirements of lignocellulosic biomass hinder the development of the lignocellulosic biorefinery. Lignocellulosic ethanol production so far, has been based mainly on single feedstocks while the use of mixed feedstocks has been poorly explored. Previous studies from alternative applications of mixed lignocellulosic biomass (MLB) have shown that their use can bring about significant cost savings when compared to single feedstocks. Although laboratoryscale evaluations have demonstrated that mixed feedstocks give comparable or even higher ethanol yields compared to single feedstocks, more empirical studies are needed to establish the possibility of achieving significant cost savings in terms of pre-biorefinery logistics. In this review, some potential benefits of the use of MLB for ethanol production are highlighted. Some anticipated limitations of this approach have been identified and ways to surmount them have been suggested. The outlook for ethanol production from MLB is promising provided that revolutionary measures are taken to ensure the sustainability of the industry.
\end{abstract}

Khanom Simarani

hanom_ss@um.edu.my; hanomks@gmail.com

1 Institute of Biological Sciences, Faculty of Science, University of Malaya, 50603 Kuala Lumpur, Malaysia

2 Department of Microbiology, Faculty of Life Sciences, University of Ilorin, P.M.B. 1515, Ilorin, Nigeria
Keywords Bioethanol · Biofuel · Bioprocessing · Biorefinery $\cdot$ Mixed substrates $\cdot$ Lignocellulosic biomass

\section{Introduction}

Problems associated with the use of fossils as sources of fuels have positioned biofuels as viable alternatives. This is evident in the exponential increase in the consumption of biofuels in recent times [1]. Such problems include environmental concerns (global warming), depleting oil reserves, fluctuating oil prices and regional conflicts over resource control (e.g. Nigeria and South Sudan) [1-3]. The use of biofuels can overcome these problems as well as encouraging socio-economic development of rural communities [4]. Bioethanol is the most utilized non-fossil fuel for transportation globally. It can serve as an additive or substitute to gasoline and it is well-suited for automobile engines $[4,5]$. Additionally, bioethanol has other varied uses which make it a highly valuable commodity. It can be used in domestic cooking as ethanol gels [6], in fuel cells [7], for hydrogen production and as a precursor for other chemical commodities [8].

Current commercial production of bioethanol is primarily based on sugar and starch crops (first-generation feedstock) [9]. The use of such feedstock is considered unsustainable due to competition with land and water, which are meant for food production; and unethical due to the controversial role in causing increase in food prices. Second-generation feedstocks in the form of lignocellulosic biomass are sustainable and fair alternatives because they are cheap, abundant and they do not exert undue pressure on land and food [10]. Lignocellulose is composed of cellulose and hemicellulose carbohydrate polymers which are held together by lignin. The sugar 
monomers present in the carbohydrate polymers can be converted into ethanol via fermentation after hydrolysis using chemicals or cellulolytic and hemicellulolytic enzymes [4]. Lignocellulosic biomass is widely available in the form of agricultural residues, wood and forest residues, dedicated energy crops and grasses, industrial wastes and organic component of municipal solid wastes [11]. Since most of these materials are regarded as waste, utilizing them for ethanol production is a means of relieving the environment of potential hazards. Moreover, their use in ethanol production has a lower net energy balance and lower greenhouse gases emissions and they are adaptable for use on marginal lands which are not suitable for food crops $[9,10]$. Additionally, only lignocellulosic ethanol has the potential to be produced and consumed sustainably under socio-economic considerations [12].

In spite of its advantages, production of lignocellulosic ethanol at present is considered not cost-effective and has not been fully deployed on a commercial scale. The high cost of lignocellulosic ethanol production has been attributed primarily to high cost of the feedstock supply chain and technology bottlenecks in the conversion of the biomass to ethanol $[11,13]$. These problems lead to fluctuation in the supply of the feedstock to the biorefinery and also contribute in making the process more expensive. Factors hindering the full-scale production of lignocellulosic ethanol can be categorized into three groups, and they are highlighted as follows:

1. Logistics issues. Harvesting, collection, pre-processing, storage and transportation, which all precede the arrival of the feedstock at the biorefinery gate, affect the cost and availability of the raw materials [13]. Typical logistics costs of biomass were estimated as US\$19-35 for collection of biomass in various forms, about US $\$ 31$ for pellet production and approximately US\$6 per ton per kilometre for truck and US $\$ 17$ per ton per kilometre for rail transportation [14]. According to another study [15], these handling and transportation activities may constitute up to $20-50 \%$ of biomass delivered costs.

2 . Intrinsic characteristics. The low bulk density of lignocellulosic biomass makes its handling, processing and transportation inefficient, thus creating the need for additional costs [15]. This is also responsible for low product yields of lignocellulosic ethanol as the material is not entirely composed of the desired utilizable components (cellulose and hemicellulose) [11]. The recalcitrant nature of lignocellulose also necessitates the use of harsh and expensive pretreatment conditions, which are followed by hydrolysis with expensive hydrolytic enzymes (cellulases). Furthermore, most lignocellulosic biomass materials are nutritionally deficient since they are wastes that are generated after the main nutritious parts of the plants are removed. This means that there would be need for nutrient supplementation when these materials are used as substrates in fermentation processes [11].

3. Extraneous factors. These include other competing uses for the biomass (silage, domestic fuel, boiler fuel, soil enhancement, paper industry, etc.) [11]. Fluctuating weather conditions also result in seasonal availability of biomass which disrupts steady supply of feedstock for biorefinery operations. Figure 1 summarizes the important factors affecting the utilization of lignocellulosic biomass for bioethanol production.

The primary challenge to the success of lignocellulosic ethanol is that of ensuring a consistent and cost-effective supply of the feedstock to the biorefinery. For lignocellulosic ethanol production to be viable, continuous supply of biomass feedstocks at a reasonable cost must be guaranteed. These feedstocks are of diverse types and they vary according to their chemical composition, geographic location and different weather conditions, and varied harvest, storage and processing methods [16-18]. Unfortunately, given the seasonal availability of agricultural biomass, the year-round supply of any single feedstock type is not feasible. Therefore, for the biorefinery to be profitable and viable, it must be able to efficiently convert these mixed feedstock streams into ethanol at any point in time. This would require a revisit and improvement of the present technology which is predominantly based on single feedstock utilization. Previous literature on lignocellulosic ethanol has focused mainly on single feedstock conversion while the utilization of multiple substrates has received very little attention.

This review aims to draw attention to the potential benefits and possible limitations regarding the mixed biomass approach to lignocellulosic ethanol production. Analysis of relevant literature is presented and relevant gaps are identified. Ways of overcoming the anticipated challenges and improving mixed lignocellulosic biomass (MLB) processing for ethanol are also suggested.

\section{Mixed Biomass Concept}

The mixed biomass system generally involves the simultaneous utilization (processing and conversion) of two or more different biomass feedstocks in varying or equal proportions for the production of a commodity of interest rather than using a single biomass feedstock (Fig. 2). The components may be of the same or different origin (source and supply chain), they may have similar or contrasting characteristics and they may require similar or different processing techniques for their conversion. The focus of this review is on the use of mixed lignocellulosic biomass (MLB) for ethanol production. 
Fig. 1 Factors affecting lignocellulosic biomass cost and supply for bioethanol production

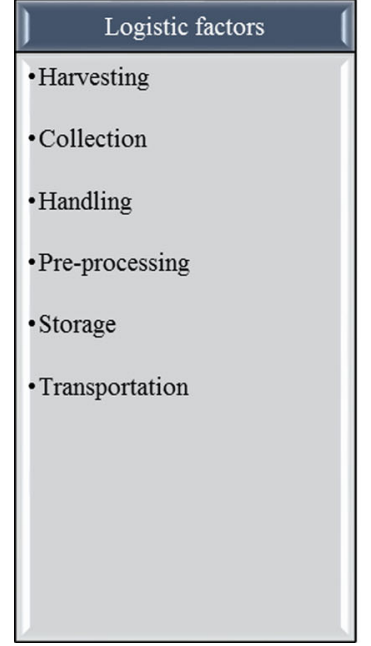

Extraneous factors

- Unstable weather: low crop yield and unstable supply

- Other competing uses for biomass

-Seasonal availability
The mixed biomass system has actually been applied for the production of other types of commodities besides ethanol. MLB have been investigated for the production of biohydrogen [19, 20], biogas/methane [21-23], polyhydroxyalkanoates [24, 25], microbial enzymes [25-27] and some power, heat, and cooling applications [13, 28-31]. Biomass has also been used in combination with coal for power generation solely [32, 33], and for combined heat and power (CHP) systems [34]. However, just as it is in the case of ethanol, the number of studies utilizing mixed biomass in these examples is few when compared to single biomass applications. This shows that adoption of MLB across these applications has the potential of improving the biorefinery concept in general.

\section{Criteria for Selection and Types of Biomass Mixture Combinations}

Generally, the relative abundance of any particular biomass in a location dictates its choice of selection for use. There are, however, many other considerations that could influence the choice of biomass components to be chosen. Most of these considerations all boil down to the issue of cost as any feedstock combination would be selected in order to increase yield, productivity and general process efficiency, which are all aimed at cost reduction. A good example is the selection of mixture components based on the need to avoid extra nutrient supplementation or detoxification of the mixture hydrolysate during downstream processing such as microbial fermentation.
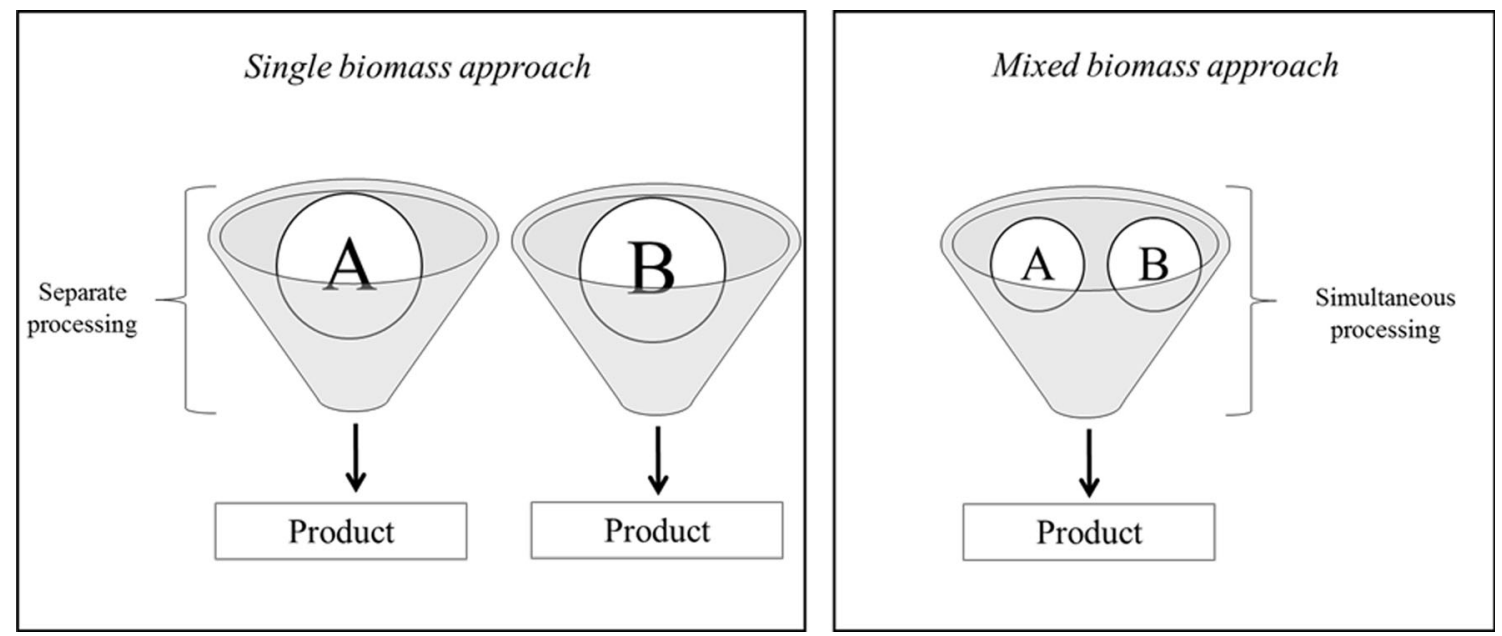

Fig. 2 Single biomass and mixed biomass approaches to lignocellulose bioprocessing. In the single biomass approach, different biomass feedstocks $(A, B)$ are processed separately to obtain a product of

interest. However, in the mixed biomass approach, such biomass feedstocks are simultaneously processed to obtain the product of interest 
Such biomass components would have sufficiently high amounts of essential nutrients such as nitrogen, sugars and other complex nutrients which reduce the need for the addition of expensive supplements such as urea [35-37]. The combination of different biomass hydrolysates in a mixture may result in lowering the concentration of inhibitors thereby reducing the need for expensive chemical detoxification process [33]. The ultimate choice of mixture components may be influenced by the concession for higher yield and concentration of ethanol as seen in the supplementation of lignocellulosic feedstock with starch-based components [33, 36, 37]. Another consideration is the proximity of the component feedstock to each other and to the point of collection or processing facility. In this case, feedstock which are available at the same location may be given preference over those that are farther away. The ease of collection would make the logistics easier and could bring about eventual cost savings. This case is exemplified in the use of forest biomass mixtures for the production of fermentable sugars for ethanol and other end-products [40]. Similarly, substrates with similar characteristics are also preferred for combination than those with contrasting characteristics due to the ease of processing using the same equipment [28]. Lastly, feedstock that are cheap and abundant can also be given preference in spite of other technical considerations due to the overall economic viability [41]. Whatever criteria the selection is based upon, the characteristics of the feedstock which may affect their upstream/downstream processing must be taken into consideration. For the process to be feasible, the costs of harvesting, collection, handling and transportation of each feedstock must not be too high. Thus, the criteria must take into consideration the technical and economic feasibility of utilizing mixed feedstock.

Diverse combinations of different types of lignocellulosic biomass have been used for the production of fermentable sugars, ethanol, and other bio-based products. Lignocellulosic materials within the same category have been used in combination (e.g. forest residues [41-43], agricultural residues, grasses [36], etc.) while some combinations cut across different categories of lignocellulosic biomass classification (e.g. forest residues + agricultural residue + grass, municipal solid wastes $[16,44-46])$. For biomass mixtures that fall within the same category, different parts of the same plant (e.g. sugar cane straw + sugar cane bagasse [47, 48]) as well as parts of different plants (e.g. rice straw + wheat bran [27, 49-51]) have been combined. In some studies, first-generation biomass feedstock (e.g. saccharified wheat meal, corn kernel) were combined with lignocellulosic biomass hydrolysates in order to increase the amount of fermentable sugars present in the hydrolysates and thereby increase the ethanol concentration [35, 38, 39, 52]. Although this type of combination involves first generation feedstocks, some researchers see it as a realistic way of migrating to full-scale second-generation ethanol. An immediate halt of first-generation ethanol production is not expected in the nearest future given the higher cost and technological barriers facing lignocellulosic ethanol production $[38,39]$. Table 1 presents a summary of various feedstock combinations as derived from available literature.

\section{Ethanol Production from MLB}

Although literature on MLB utilization is generally limited, a notable increase in the number of publications regarding ethanol production from MLB has been recorded in the last 5 years (see Table 2). Lignocellulosic biomass from a wide variety of origins has been used in combination with other lignocellulosics or with first-generation feedstocks for ethanol production. Many of the studies have indicated that ethanol production on mixed substrates is better or comparable to what is obtainable on single lignocellulosic substrates [35, 62, 67-69]. When different biomass feedstocks are to be used in combination for ethanol production, the individual substrates may be pretreated and hydrolyzed separately or jointly. In separate pretreatment/hydrolysis, hydrolysates from the single substrates are mixed prior to fermentation [69]; but for joint or combined pretreatment/hydrolysis, the resulting hydrolysate of the raw mixture is used directly for fermentation $[65,68]$. When starch-based substrates are involved, the starch hydrolysate may be diluted before use or may be used directly with the lignocellulosic hydrolysate $[35,38,52]$. Separate hydrolysis and fermentation (SHF) and simultaneous saccharification and fermentation (SSF) configurations are commonly reported for ethanol production from mixed substrates. Simultaneous saccharification and co-fermentation (SSCF) and consolidated bioprocessing (CBP) are less reported. Higher ethanol yields in the range of 90-99\% are more commonly reported for SSF of mixtures of first- and second-generation feedstock [35, 38, 70]. Whole lignocellulosic mixtures usually have lower yields in the range of $70-80 \%$ for SSF [36, 37, 65] and SHF [62, 66, 69]. This is understandable since first-generation feedstock have higher concentrations of readily fermentable sugars. Table 2 is a summary of available literature concerning the production of ethanol from lignocellulosic mixtures.

\section{Advantages of MLB Approach to Ethanol Production}

A lot of improvements in feedstock supply logistics and conversion technologies can be realized when mixed feedstock are used in the biorefinery. Additionally, this approach could also have positive environmental impacts. These improvements may bring about cost reductions in the utilization of lignocellulosic biomass since the main obstacles to 
Table 1 Feedstock mixture combinations across various categories of biomass

\begin{tabular}{|c|c|c|c|}
\hline \multicolumn{2}{|c|}{ Biomass feedstock mixture combination } & \multirow{2}{*}{$\begin{array}{l}\text { Example } \\
\text { Bark-rich sawmill residues }\end{array}$} & \multirow{2}{*}{$\begin{array}{l}\text { Reference } \\
{[41]}\end{array}$} \\
\hline \multirow{7}{*}{$\begin{array}{l}\text { Mixture of feedstock from } \\
\text { different plants }\end{array}$} & \multirow[t]{2}{*}{ Forest residues } & & \\
\hline & & Mixed hardwood & {$[42,43,53,54]$} \\
\hline & \multirow[t]{4}{*}{ Agricultural residues } & Rice straw + wheat bran & {$[27,49-51]$} \\
\hline & & Sugar cane bagasse + wheat bran & {$[55]$} \\
\hline & & $\begin{array}{l}\text { Mustard stalk and straw + wheat bran }+ \\
\text { rice straw }\end{array}$ & {$[56]$} \\
\hline & & $\begin{array}{l}\text { Oil palm empty fruit bunch + oil palm frond + } \\
\text { rice husk }\end{array}$ & {$[57]$} \\
\hline & Grasses & Prairie grasses & {$[54,58]$} \\
\hline \multirow{6}{*}{$\begin{array}{l}\text { Mixture of feedstock } \\
\text { from same plant }\end{array}$} & \multirow{2}{*}{$\begin{array}{l}\text { Second-generation feedstock } \\
\text { mixture from same plant }\end{array}$} & Sugarcane bagasse + sugarcane straw & {$[47,48]$} \\
\hline & & Wheat bran + wheat straw & {$[26,59]$} \\
\hline & \multirow{3}{*}{$\begin{array}{l}\text { Integration of second-generation } \\
\text { feedstock with first-generation } \\
\text { feedstock from same plant }\end{array}$} & Wheat straw + wheat meal & {$[35,38]$} \\
\hline & & Corn cob furfural residue + corn kernel starch & {$[39]$} \\
\hline & & Barley straw + barley grain & {$[60,61]$} \\
\hline & Whole biomass utilization & Sugarcane straw + bagasse + tops & {$[62]$} \\
\hline \multirow[t]{7}{*}{$\begin{array}{l}\text { Second-generation } \\
\text { feedstock mixtures }\end{array}$} & Agricultural residue + forest residue + grass & $\begin{array}{l}\text { Corn stover }+ \text { switch grass }+ \text { lodge pole pine }+ \\
\text { eucalyptus }\end{array}$ & {$[16]$} \\
\hline & \multirow[t]{2}{*}{ Forest residue + grass } & Aspen + balsam + switch grass & {$[40]$} \\
\hline & & $\begin{array}{l}\text { Aspen/basswood/red maple/balsam + } \\
\text { switch grass }\end{array}$ & {$[63]$} \\
\hline & Agricultural residue + forest residue & $\begin{array}{l}\text { Sawdust of rubber wood }+ \text { mixed hardwood }+ \\
\text { oil palm trunk }\end{array}$ & {$[64]$} \\
\hline & Grass + legume & Clover + ryegrass & {$[36]$} \\
\hline & Municipal solid wastes + agricultural residue & \multirow[t]{2}{*}{ Municipal solid wastes + wheat straw } & {$[65,66]$} \\
\hline & $\begin{array}{l}\text { Municipal solid wastes/mixed solid } \\
\text { wastes }\end{array}$ & & [44-46] \\
\hline $\begin{array}{l}\text { Integration of } \\
\text { second-generation } \\
\text { with first-generation } \\
\text { feedstock }\end{array}$ & & Spruce chips + wheat flour hydrolysate & {$[52]$} \\
\hline
\end{tabular}

lignocellulose bioprocessing are related to logistics and conversion processes [11]. Generally, there is scarcity of literature regarding the cost benefits of the MLB approach. The few that are available only focused on the upstream logistics of MLB use and for other applications besides ethanol production. Although the feasibility of MLB use for ethanol production has been demonstrated at the laboratory scale, there are currently no empirical studies that focused on the possible cost benefits. Notwithstanding, since upstream processes such as transportation are peculiar to most lignocellulosic applications, the lignocellulosic ethanol biorefinery may also derive some of the benefits that are obtainable in these stages. The advantages of MLB use can be categorized into three and they are discussed in the following sections.

\section{Improved Logistics and Associated Cost Reductions}

When multiple feedstocks are incorporated into existing single feedstock-based biorefineries, there would be increased throughput as a result of the additional feedstock processing.
This may translate into cost reductions for the biorefinery. This could also maximize the scale of the biorefinery and bring about economy of scale benefit. Currently, no biorefinery operates at a capacity larger than 7000 dry tonnes per day due to feedstock availability issues [71]. The use of mixed feedstock would ensure continuous availability thereby allowing for expansion of the capacity of the biorefinery. Cost of production could then reduce as a result of the economic optimum size of the biorefinery at the large scale [71].

In the single biomass system, the seasonality of supply necessitates extensive storage of large amounts of the biomass for significant period of time in order to achieve year-round running of the processing facility. Because the time-frame required for collecting this huge amount of biomass is limited, the demand for resources such as equipment, workforce and storage also becomes seasonal, and this increases their costs and leads to suboptimal utilization [72]. However, with the multiple biomass system, the seasonal availability is avoided; therefore, the attendant increase in cost of resources is also avoided. More so, in the case of storage, significant cost 
Table 2 Studies utilizing MLB for ethanol production

\begin{tabular}{|c|c|c|c|c|c|}
\hline $\begin{array}{l}\text { Mixture } \\
\text { components }\end{array}$ & $\begin{array}{l}\text { Configuration/ } \\
\text { fermenting } \\
\text { microorganism(s) }\end{array}$ & Mixture pretreatment/type & Objective(s) & Findings & Ref. \\
\hline $\begin{array}{l}\text { Sugarcane bagasse } \\
\text { and ricotta whey }\end{array}$ & $\begin{array}{l}\text { SSF; } \\
\text { Kluyveromyce- } \\
\text { s marxianus } \\
\text { CCT } 7735\end{array}$ & Separate; acid (bagasse) & $\begin{array}{l}\text { Optimization of ethanol } \\
\text { production }\end{array}$ & $\begin{array}{l}49.65 \mathrm{~g} / \mathrm{L} \text { highest ethanol yield at } \\
\text { optimum conditions }\end{array}$ & [67] \\
\hline $\begin{array}{l}\text { Waste copier paper } \\
\text { and wheat straw }\end{array}$ & $\begin{array}{l}\text { SSF; } S \text {. } \\
\quad \text { cerevisiae } \\
\text { NCYC } 2826\end{array}$ & Combined; steam explosion & $\begin{array}{l}\text { Effect of paper as co-substrate } \\
\text { on pretreatment and ethanol } \\
\text { production }\end{array}$ & $\begin{array}{l}\text { Reduction in inhibitor levels; higher } \\
\text { ethanol yield after } 24 \mathrm{~h}\end{array}$ & {$[68]$} \\
\hline $\begin{array}{l}\text { Municipal solid } \\
\text { waste }\end{array}$ & $\begin{array}{l}\text { SHF; } S . \\
\quad \text { cerevisiae }\end{array}$ & Combined; acid & $\begin{array}{l}\text { Ethanol production on MSW } \\
\text { from different locations }\end{array}$ & Maximum ethanol conc. $0.15 \mathrm{~g} / \mathrm{L}$ & {$[44]$} \\
\hline $\begin{array}{l}\text { Wood wastes, } \\
\text { wheat straw, } \\
\text { waste papers }\end{array}$ & $\begin{array}{l}\text { SHF; } S . \\
\text { cerevisiae }\end{array}$ & $\begin{array}{l}\text { Combined; acid-assisted } \\
\text { steam explosion }\end{array}$ & $\begin{array}{l}\text { Effect of pretreatment on } \\
\text { ethanol production }\end{array}$ & $80 \%$ (of theoretical) ethanol yield & {$[66]$} \\
\hline $\begin{array}{l}\text { Clover-grass and } \\
\text { wheat }\end{array}$ & $\begin{array}{l}\text { SSF; commercial } \\
\text { yeast }\end{array}$ & Combined; wet oxidation & $\begin{array}{l}\text { Effect of mixture proportion } \\
\text { on ethanol yield }\end{array}$ & $\begin{array}{l}85: 15 \text { straw and clover-grass proportion } \\
\text { gave highest ethanol yield ( } 80 \% \text { of } \\
\text { theoretical) }\end{array}$ & {$[37]$} \\
\hline $\begin{array}{l}\text { Spruce chips and } \\
\text { wheat flour } \\
\text { hydrolysate }\end{array}$ & $\begin{array}{l}\text { SHF, } S \text {. } \\
\quad \text { cerevisiae } \\
\quad \text { ATCC } 96581\end{array}$ & $\begin{array}{l}\text { Separate; acid (spruce), } \\
\text { commercial amylase and } \\
\text { amyloglucosidase (wheat) }\end{array}$ & $\begin{array}{l}\text { Effects of medium } \\
\text { supplementation and cell } \\
\text { retention methods on } \\
\text { ethanol production }\end{array}$ & $\begin{array}{l}\text { Additional supplementation with } \\
\text { ammonium sulphate and biotin } \\
\text { promoted hexose utilization } \\
\text { compared to wheat hydrolysate } \\
\text { supplementation only; } \\
\text { immobilization supported higher } \\
\text { ethanol production }\end{array}$ & {$[52]$} \\
\hline $\begin{array}{l}\text { Cassava residues } \\
(\mathrm{CR}) \text { and furfu- } \\
\text { ral residues (FR) }\end{array}$ & $\begin{array}{l}\text { SSF; } S . \\
\quad \text { cerevisiae }\end{array}$ & $\begin{array}{l}\text { Separate; heat liquefaction, } \\
\text { commercial amylase and } \\
\text { glucoamylase (CR) }\end{array}$ & $\begin{array}{l}\text { Effect of mixture ratios and } \\
\text { substrate conc. on ethanol } \\
\text { production }\end{array}$ & $\begin{array}{l}\mathrm{CR} / \mathrm{FR}=2: 1 \text { and } 12 \% \text { substrate } \\
\text { concentration produced highest } \\
\text { ethanol yield ( } 71.7 \% \text { of theoretical) }\end{array}$ & {$[70]$} \\
\hline $\begin{array}{l}\text { Wheat straw and } \\
\text { wheat meal }\end{array}$ & $\begin{array}{l}\text { SSF; ordinary } \\
\text { baker's yeast }\end{array}$ & $\begin{array}{l}\text { Separate; steam (wheat } \\
\text { straw), liquefaction and } \\
\text { pre-saccharification with } \\
\text { commercial enzymes } \\
\text { (wheat meal) }\end{array}$ & $\begin{array}{l}\text { Effect of substrate } \\
\text { combination on ethanol } \\
\text { production }\end{array}$ & $\begin{array}{l}\text { Mixture gave higher ethanol yield (\% } \\
\text { theoretical, } 99 \%) \text { than pretreated } \\
\text { straw }(68 \%) \text { or pre-saccharified } \\
\text { wheat meal }(91 \%) \text { only }\end{array}$ & {$[35]$} \\
\hline $\begin{array}{l}\text { Wheat straw and } \\
\text { wheat meal } \\
\text { (saccharified, } \\
\text { SWM or } \\
\text { fermented, } \\
\text { FWM) }\end{array}$ & $\begin{array}{l}\text { SSF (baker's } \\
\text { yeast), SSCF } \\
\text { (S. cerevisiae } \\
\text { KE6-12) }\end{array}$ & $\begin{array}{l}\text { Separate; steam (wheat } \\
\text { straw), liquefaction and } \\
\text { saccharification (wheat } \\
\text { meal), fermentation (wheat } \\
\text { meal) }\end{array}$ & $\begin{array}{l}\text { Effect of wheat meal } \\
\text { supplementation type, } \\
\text { process configuration, and } \\
\text { fermentation mode on } \\
\text { ethanol production }\end{array}$ & $\begin{array}{l}\text { SSF with SWM gave highest ethanol } \\
\text { yield compared to other modes } \\
\text { studied }\end{array}$ & {$[38]$} \\
\hline $\begin{array}{l}\text { Rice hull }(\mathrm{RH}) \text { and } \\
\text { cotton stalk (CS) }\end{array}$ & $\begin{array}{l}\mathrm{SHF} ; E . \text { coli } \\
\mathrm{KO} 11\end{array}$ & Separate; acid & $\begin{array}{l}\text { Effect of single vs. various } \\
\text { substrate combinations on } \\
\text { ethanol production }\end{array}$ & $\begin{array}{l}70 \% \mathrm{RH}, 30 \% \mathrm{CS} \text { gave highest ethanol } \\
\text { yield ( } 0.44 \mathrm{~g} \text { ethanol/g sugar) }\end{array}$ & [69] \\
\hline $\begin{array}{l}\text { Clover and rye } \\
\text { grass }\end{array}$ & $\begin{array}{l}\text { SSF; } S \text {. } \\
\text { cerevisiae and } \\
\text { Mucor indicus } \\
\text { CCUG } 22424\end{array}$ & Combined; wet oxidation & $\begin{array}{l}\text { Effect of pretreatment on } \\
\text { ethanol production from un- } \\
\text { supplemented medium by } \\
\text { yeast and mould }\end{array}$ & $\begin{array}{l}\text { 86-88\% cellulose conversion; } \\
\text { additional nutrient supplementation } \\
\text { not necessary for ethanol production }\end{array}$ & {$[36]$} \\
\hline $\begin{array}{l}\text { Municipal } \\
\text { household waste } \\
\text { and wheat straw }\end{array}$ & $\begin{array}{l}\text { SSF; } S . \\
\quad \text { cerevisiae }\end{array}$ & Combined; wet oxidation & $\begin{array}{l}\text { Effect of pretreatment } \\
\text { parameters and enzyme } \\
\text { loadings on ethanol } \\
\text { production }\end{array}$ & $\begin{array}{l}60-65 \% \text { ethanol yields obtained at } \\
\text { conditions studied and with moderate } \\
\text { enzyme loadings }\end{array}$ & {$[65]$} \\
\hline $\begin{array}{l}\text { Sugarcane residues } \\
\text { (bagasse, straw } \\
\text { and hops) }\end{array}$ & $\begin{array}{l}\text { SHF; } S \text {. } \\
\text { cerevisiae } \\
\text { CAT-1 }\end{array}$ & Combined; acid & $\begin{array}{l}\text { Ethanol production on single } \\
\text { vs. mixed substrates; effect } \\
\text { of sugarcane variety of } \\
\text { ethanol production }\end{array}$ & $\begin{array}{l}25 \% \text { higher ethanol yield on mixture } \\
\text { compared to bagasse only; sugarcane } \\
\text { variety not a significant factor }\end{array}$ & {$[62]$} \\
\hline
\end{tabular}

savings may be realized since the space required would be reduced as a result of the smoother inflow of biomass all year-round [72]. Feedstock supply to the biorefinery would also be more reliable and consistent because different feedstocks could complement each other as inputs in the biorefinery during the low supply periods of either of them 
$[13,28]$. This stable feedstock supply will lead to increased operational efficiency which will consequently reduce labour and equipment costs. More so, the reduced storage requirements and improved feedstock supply will allow for smooth and uninterrupted year-round running of the biorefinery, thereby maximizing biomass utilization and the scale of the processing facility. The continuous running of the biorefinery would also mean that cheaper means of storage can be used for the mixed feedstock. This is because the feedstock would not need to be stored for long periods which would have necessitated the use of more expensive storage facilities.

MLB use could also bring cost savings due to the complementarity of the integrated feedstocks. In a dynamic simulation modelling study [28], which aimed at reducing costs in the use of biomass for district heating applications, it was concluded that up to 15-20\% cost reductions can be achieved when using reed canary grass (RCG) and wheat straw as fuel source than when using straw alone. The authors further projected that the lowest possible cost would be achieved if a mix of straw and wood chips complemented with RCG was used. They attributed this to the more efficient use of machines, storage space and optimal fuel proportions. The complementary effect of RCG also contributed significantly to cost reduction by reducing the amount of the expensive oil that is normally used when straw is the sole fuel source.

Another benefit of the MLB system is that it can ensure viability of biomass supply. Most biomass being agricultural materials are susceptible to a lot of risks, e.g. climatic unpredictability, diseases, pests, floods, cyclones, etc. The use of mixed and diverse types of biomass would be able to minimize the risks that are associated with a single type of biomass by providing a buffering effect on the supply during periods of interruption [73].

Cost reductions related to feedstock transportation can also be achieved when mixed feedstocks are used in a biorefinery. It was shown that delivery cost for mixtures of woody and agricultural biomass was lower than the delivery cost of single biomass types [71]. Such lower delivery costs can be achieved if appropriate forms (loose biomass, bales, chips, pellets) of each biomass type at certain mixture proportions are used. The authors found that delivery of feedstock mixture comprising $30 \%$ agricultural biomass bales and $70 \%$ wood chips to the biorefinery was more economical than if $100 \%$ of either type was delivered (Table 3).

\section{Technological Benefits}

The prospect of ethanol production from mixed biomass has been demonstrated at the laboratory scale (Table 4). Studies have shown that in most cases, when single substrates are combined, ethanol yields from the mixtures are usually higher, or at worst, of intermediary yields compared to the single substrates [35, 38, 62, 67-69]. This may generally be attributed to the
Table 3 Logistic benefits and cost reductions associated with mixed biomass utilization

\begin{tabular}{|c|c|c|c|}
\hline Biomass Feedstocks & Application & $\begin{array}{l}\text { Improvement/benefit } \\
\text { achieved }\end{array}$ & Reference \\
\hline Straw and RCG & $\begin{array}{r}\text { Bioenergy } \\
\text { (district } \\
\text { heating) }\end{array}$ & $\begin{array}{l}\text { 15-20\% cost } \\
\text { reductions with } \\
\text { biomass mixture } \\
\text { compared to using } \\
\text { straw only }\end{array}$ & {$[28]$} \\
\hline $\begin{array}{l}\text { Different forms of } \\
\text { agricultural (wheat } \\
\text { straw, corn stover) } \\
\text { and woody (forest) } \\
\text { biomass }\end{array}$ & Biorefinery & $\begin{array}{l}\text { Lowest delivery cost } \\
\text { achieved with } 70 \% \\
\text { wood chips and } \\
30 \% \text { agricultural } \\
\text { biomass bales than } \\
\text { with } 100 \% \text { of either } \\
\text { biomass types }\end{array}$ & {$[71]$} \\
\hline
\end{tabular}

complementary or synergistic effects of the single substrates after they are combined. The desirable characteristics of different feedstocks may be combined or the beneficial characteristics of one feedstock could compensate for another with less desirable features. Furthermore, materials with similar characteristics can be processed easily using the same equipment (e.g. woody biomass types, cereal stalks) [28].

In the conventional monoculture feedstock system of bioethanol production, additional nutritional supplementation is usually required in order to promote the metabolism of fermenting microorganisms for the purpose of increasing the product yield. In a process where more than one biomass feedstock is used as the fermentation substrate, one of the components of the mixture may provide the needed nutritional supplementation to the organisms thereby reducing the need for the addition of expensive supplements. For example, the addition of urea as a supplement during the SSCF fermentation of wet oxidation pretreated clover-ryegrass mixtures by Saccharomyces cerevisiae and Mucor indicus did not have any significant effect on the ethanol yield as the nitrogen content of the hydrolysates was sufficient for the fermentation [36]. Similarly, a high yield of ethanol ( $80 \%$ of theoretical yield) was obtained when straw was supplemented with high fraction of clover-grass without any additional nitrogen supplementation [37]. This reduced need for extraneous nutrient supplementation would translate into reduced production costs. In cases such as these, the mixture of different substrates creates an adequate balance of carbon-nitrogen ratio which is suitable for the fermentation process.

Combination of some feedstock types may reduce the amounts of inhibitors present in the hydrolysate and increase ethanol yields. The detoxifying effect of copier paper on wheat straw hydrolysate was demonstrated by [68]. Waste copier paper, wheat straw and their mixtures were subjected to steam explosion pretreatment and the liquors were subsequently fermented by $S$. cerevisiae to produce ethanol. It was 
Table 4 Technological benefits and improvements associated with mixed biomass utilization

\begin{tabular}{|c|c|c|c|}
\hline $\begin{array}{l}\text { Biomass } \\
\text { feedstocks }\end{array}$ & Application & $\begin{array}{l}\text { Improvement/benefit } \\
\text { achieved }\end{array}$ & Reference \\
\hline $\begin{array}{l}\text { Sugarcane } \\
\text { residues } \\
\text { (bagasse, } \\
\text { straw and } \\
\text { hops) }\end{array}$ & $\begin{array}{l}\text { Ethanol } \\
\text { production }\end{array}$ & $\begin{array}{l}55 \% \text { higher enzymatic } \\
\text { conversion and a } 25 \% \\
\text { higher ethanol yield } \\
\text { with mixture than with } \\
\text { bagasse alone }\end{array}$ & {$[62]$} \\
\hline $\begin{array}{l}\text { Waste copier } \\
\text { paper and } \\
\text { wheat straw }\end{array}$ & $\begin{array}{l}\text { Ethanol } \\
\text { production }\end{array}$ & $\begin{array}{l}\text { Reduction in inhibitor } \\
\text { levels in the mixture } \\
\text { compared to single } \\
\text { substrates; reduced lag } \\
\text { period in fermentation } \\
\text { for mixture }\end{array}$ & [68] \\
\hline $\begin{array}{l}\text { Clover and rye } \\
\text { grass }\end{array}$ & $\begin{array}{l}\text { Ethanol } \\
\text { production }\end{array}$ & $\begin{array}{l}\text { High cellulose } \\
\text { conversion to ethanol } \\
\text { achieved in the } \\
\text { mixture without need } \\
\text { for urea } \\
\text { supplementation }\end{array}$ & [36] \\
\hline $\begin{array}{l}\text { Wheat straw } \\
\text { and clover- } \\
\text { grass mixture }\end{array}$ & $\begin{array}{l}\text { Ethanol } \\
\text { production }\end{array}$ & $\begin{array}{l}\text { High ethanol yield } \\
\text { obtained in the } \\
\text { mixture without } \\
\text { additional nitrogen } \\
\text { supplementation }\end{array}$ & [37] \\
\hline $\begin{array}{l}\text { Oil palm and } \\
\text { rice residues }\end{array}$ & $\begin{array}{l}\text { Endoglucanase } \\
\text { production }\end{array}$ & $\begin{array}{l}\text { Endoglucanase } \\
\text { production was one- to } \\
\text { sevenfolds higher on } \\
\text { mixed substrate than } \\
\text { on single pure cellu- } \\
\text { losic and lignocellu- } \\
\text { losic substrates }\end{array}$ & [57] \\
\hline $\begin{array}{l}\text { Wheat straw } \\
\text { and hybrid } \\
\text { poplar }\end{array}$ & $\begin{array}{l}\text { Fermentable } \\
\quad \text { sugar } \\
\text { production }\end{array}$ & $\begin{array}{l}\text { Mixed biomass gave } \\
\text { higher sugar recovery } \\
\text { after pretreatment, } \\
\text { reduced sugar } \\
\text { degradation, and } \\
\text { higher sugar yield } \\
\text { after enzymatic } \\
\text { saccharification than } \\
\text { either of the single } \\
\text { biomass }\end{array}$ & [74] \\
\hline $\begin{array}{l}\text { Wheat bran } \\
\text { (WB) and } \\
\text { sesame oil } \\
\text { cake (SOC) }\end{array}$ & $\begin{array}{l}\text { Phytase } \\
\text { production }\end{array}$ & $\begin{array}{l}\text { WB-SOC mixture gave } \\
\text { higher phytase yield } \\
\text { than either of the } \\
\text { single substrates }\end{array}$ & {$[75]$} \\
\hline
\end{tabular}

found that the levels of inhibitors (acetic acid, formic acid, $5 \mathrm{HMF}$ ) in the mixture liquor were much lower than those in the single substrates. After $24 \mathrm{~h}$ of fermentation, ethanol yield of the mixture was $34 \%$ compared to $3 \%$ yield recorded on pretreated straw only. The authors further showed that incorporating waste paper with straw could have the same detoxifying effect as pure $\mathrm{CaCO}_{3}$ would have on filter paper. Although the mixture ethanol yield after $72 \mathrm{~h}$ was lower than that of straw alone, higher yield at $24 \mathrm{~h}$ showed that mixing the substrates reduced the lag period. This would allow for higher throughput industrially and could increase profitability of the biorefinery.

The use of integrated first- and second-generation feedstocks in ethanol production could also reduce production costs. Since lignocellulosic hydrolysates usually have low sugar concentrations, addition of starchy biomass into a lignocellulosic process could increase ethanol yields by increasing fermentable sugar concentrations. This would reduce higher energy demand that is associated with distillation of low ethanol concentrations [35]. It is also possible to have valuable co-products, e.g. protein-rich solid residues when such combinations are used [38].

\section{Environmental Benefits}

The use of mixed biomass feedstocks in ethanol production has some benefits from an environmental sustainability perspective. The accumulation of municipal solid wastes (MSW) is a huge problem in many metropolitan settings worldwide. Some of the measures taken to dispose these wastes, such as burning, usually increase environmental pollution. The landfill option which is another avenue for utilizing the wastes has faced some restrictions, with the European Union placing limits on landfill use and the amount of biodegradable MSW used for this purpose [45]. Besides, landfilling costs have been on the increase in recent times [68]. Therefore, conversion of the organic fractions of these wastes to ethanol is a viable alternative for MSW management. In Malaysia, open burning of wastes is legally prohibited [76] thus creating the need for alternative ways of managing them [76]. Previous studies have demonstrated the feasibility of converting mixed lignocellulosic waste streams from municipal waste sources to ethanol $[44,45,65]$.

Additionally, there is the possibility of having a better net energy balance when mixed biomass sources are processed for ethanol than when single sources are processed separately. The better process efficiency and better use of equipment and facilities will likely bring about a greater energy output from the process compared to when they are processed separately. This possibility, however, needs to be evaluated from empirical studies and life cycle assessments as there is a dearth of literature in this regard. As it is one of the goals of the second-generation biorefinery to reduce the use of fossilderived chemicals, the use of mixed lignocellulosic feedstocks could make it possible. It has been demonstrated that combination of some feedstock types reduces the need for addition of fossil-derived detoxifying chemicals or mineral nutrient supplements during fermentation [35-39]. This is attributed to the dilution of inhibitors that occurs when hydrolysates from different feedstock are mixed, creating a self-detoxification effect. Furthermore, such combined hydrolysates may contain 
sufficient levels of naturally occurring nutrients present in the individual feedstocks.

\section{Limitations and Problems of MLB Approach to Bioethanol}

With the exception of biogas production via the anaerobic co-digestion route [21-23, 77], the amount of literature available with respect to the use of mixed lignocellulosic biomass sources for bioenergy applications is limited compared to those of single feedstocks. This can be attributed to the limitations and challenges associated with this approach [72]. These limitations are basically related to technical and logistic issues which arise from the diverse nature of the biomass sources.

Because the mixture components may have widely varying characteristics such as amounts of moisture, ash, cellulose, hemicellulose and lignin, particle sizes and distribution, bulk density, etc. $[17,18]$, the choice of a suitable processing method which would be optimal for all the mixture components might be difficult to make as different feedstocks have different optimal conditions for pretreatment, hydrolysis and fermentation. Besides, mixed streams of lignocellulosic residues and wastes have a higher degree of contamination compared to single feedstocks [31]. Finding an ideal pretreatment and hydrolysis conditions that would release optimum amount of sugar and generate low inhibitors from a combination of feedstocks would require a lot of time-consuming preliminary studies; and in reality, compromises would have to be made. This is likely to reduce the profitability and efficiency of the process. An array of commercial enzymes which are wellsuited to the diverse and contrasting polysaccharide contents of the mixtures must also be provided in order to have a good yield of sugars from them. This would likely contribute to higher production costs.

Besides that, the mixed carbon sources arising from the combined substrates may result in the problem of catabolite repression for the fermenting microorganism especially when the carbon sources are available in high concentrations. Some microorganisms tend to utilize carbon sources simultaneously only when the substrates are available in limited quantity, but when available in high amounts, they utilize the substrates in a sequential manner [78, 79], which in a practical sense, would lead to poor productivity. This constitutes a formidable challenge to the profitability of the entire process as high sugar concentrations are required for good yield of ethanol from fermentation.

Similarly, since mixed feedstocks are likely to have different lignin composition, a fermenting microorganism's effectiveness might be reduced by the lignin component of one of the feedstocks regardless of the fact that it does well on the other mixture component(s). Same applies in the case of enzymatic hydrolysis. Lignin is known to have an inhibitory action against cellulases and microorganisms [80-82]. This problem could make the process uneconomic as the yield and productivity would be affected.

Logistics can become complicated when multiple biomass sources are utilized in the bioethanol production process. This is especially true when the feedstocks are available in unsuitable forms and of low bulk density [71]. Different biomass types require different types of equipment for collection, handling, loading and transportation. When multiple biomass streams are involved, the logistics can become quite challenging and the cost of this may undermine the potential capital cost savings associated with the system [72]. For seasonal biomass types, harvesting the biomass at a period which differs from its proper harvesting date, for the sake of making different feedstock components of the mixed stream available to the biorefinery at the same time for processing might affect the quality of the biomasses for bioethanol production. This is because harvesting time influences the chemical characteristics and bioethanol potential of some biomass types [83, 84].

Adapting the existing cellulosic bioethanol plants for mixed biomass processing might also be difficult to achieve. This is because bioethanol plants are usually cited close to the source of the existing feedstock whose location might be far from that of any other feedstock to be combined with it. This is likely to lead to increased cost of transportation. Besides, the existing machinery may have been designed to suit the processing of a particular type of feedstock only and using it for a different feedstock type or for mixtures might give unsatisfactory results.

Other aspects of the system such as organization, variations in availability, storage and back up of biomass at different seasons are issues that also need to be examined in detail $[31,72]$.

\section{Overcoming the Barriers of Mixed Feedstock Approach to Lignocellulosic Ethanol}

Because literature on mixed biomass approach are generally limited, studies on functional tested strategies regarding overcoming the cost implications of MLB logistics are very rare at the moment. However, laboratory studies on ethanol production from MLB indicate that the anticipated challenges of MLB use can be overcome if strategic steps are taken. Although any proffered strategy at the moment may seem speculative, the fact that some of the measures discussed in this section have been successfully employed in other applications of MLB makes the use of MLB for bioethanol production promising. 


\section{Feedstock Supply and Logistics-Related Strategies}

\section{Delivery of Mixed Feedstocks in Appropriate Forms and Optimal Proportions}

Delivery costs can be lowered significantly if feedstocks are combined in certain forms and at appropriate proportions. As seen in [71], delivery of different forms of biomass mixtures (as bales, chips, pellets or chopped forms) at different proportions incurred widely varying costs. The authors showed that delivery of feedstock mixtures in the form of wood chips and agricultural bales was the most economical and that $70 \%$ wood chips and $30 \%$ agricultural bales was the combination incurring the lowest delivery cost. This is as a result of the interplay of various factors involved in the feedstock supply chain. Such factors include biomass bulk density, transportation distance, biorefinery capacity and costs of harvesting, pre-processing, storage and in-plant processing [71]. Therefore, these factors should be considered carefully when planning the logistics of a biorefinery that would handle mixed feedstocks.

\section{Strategic Siting of Biorefineries}

Future biorefineries that will be based on MLB could be constructed at a location which is equidistant from the sources of all the feedstocks to be co-processed. Alternatively, the siting of the biorefinery could be done such that minimum distance possible would be considered while using the classification scheme presented in Table 1. This problem might be unimportant for feedstocks originating from the same plant. However, for feedstocks that are derived from different plants and across different categories of biomass, a central location for the biorefinery would be of utmost benefit.

\section{Mixed Cropping}

Mixed cropping (also known as intercropping) involves the growing of two or more species of plants simultaneously on the same piece of land [37]. This farming strategy allows the strategic selection of plant biomass types for the purpose of achieving an almost perfect medium (at the end of harvesting) which has sufficient nutrient composition for microbial fermentation in the conversion of the biomass to ethanol. For example, cereals (wheat, corn, sorghum) can be planted with nitrogen-rich legumes on the same piece of land such that the combination of the residues after harvesting creates an ideal fermentation medium which eliminates the need for additional nutrient supplementation from fossil-derived materials. This has the potential to bring about cost reductions and other additional benefits. It has been shown that the intercropping of wheat with clover grass can yield up to extra $1000 \mathrm{~kg}$ ethanol ha ${ }^{-1}$ compared to when both plants are grown separately [37]. This is in addition to the reduced need for fertilizers as a result of nitrogen fixation by clover and the benefit of grains for food and feed.

\section{Decentralized Biorefinery}

The centralized nature of lignocellulosic biorefineries handling and processing large amounts of biomass in a single location is a major challenge to bioethanol production. In a mixed biomass scenario, this problem even becomes more aggravated considering the diverse nature of the feedstocks, supply interruptions and the logistic costs involved for each type of feedstock. The establishment of regional biomass processing depots (RBPDs), which "procure, preprocess/pretreat, densify and deliver feedstock to the biorefinery and return byproducts such as animal feed to end users" [85] has been proposed as a way of addressing the drawbacks of the centralized processing system. RBPDs can process the multiple streams of lignocellulosic biomass originating from each location to have uniform characteristics before they are finally conveyed to the main biorefinery for pretreatment, hydrolysis and fermentation. A comparative life cycle analysis [85] has shown that this decentralized system could generate the same total energy as the centralized system with lower amounts of greenhouse gas emissions.

\section{Technology-Related Strategies}

\section{Use of Optimum Mixture Ratios}

Optimal yields of ethanol can be obtained during the fermentation of MLB if appropriate ratios of the feedstock components are used. Since different feedstock vary in the characteristics (e.g. glucan/xylan content, nutrients, susceptibility to pretreatment, enzymatic convertibility, etc.) which make them suitable for ethanol production, it is necessary that those with more desirable properties be in higher proportion. For example, it was reported that rice hull (RH)-cotton stalk (CS) mixtures containing higher amounts of $\mathrm{RH}$ gave higher ethanol yields when fermented by Escherichia coli KO11 [69]. This was attributed to the fact that RH was more susceptible to the acid pretreatment, and thus higher fractions of $\mathrm{RH}$ gave more fermentable sugars which resulted in higher ethanol yields compared to those with higher fractions of CS. Therefore, the problem of low ethanol yields with lignocellulosic ethanol could be managed through the careful selection of appropriate ratios of mixed feedstocks. This can be achieved through the use of mixture designs and response surface methodology in selecting optimal substrate component proportions for ethanol production. This approach has been successfully applied in 
the production of biohydrogen [19] and glutaminase [86] from mixed lignocellulosic substrates.

\section{Use of Specially-Tailored Enzyme Cocktails}

Given the diverse and heterogeneous structural composition of MLB, the conventional one-enzyme-at-a-time approach would not be suitable for most types of combinations. The use of multi-component enzyme cocktails which are targeted/designed to suit the compositional characteristics of specific biomass combinations would be necessary. An automated, high throughput system known as GENPLAT has been effectively used to optimize enzyme mixtures for the hydrolysis of diverse lignocellulosic feedstock/pretreatment combinations. The system uses an integrated robotic liquid handling, statistical experimental design and automated sugar assay to rapidly produce optimized mixtures from a 16-component core and accessory enzyme collection for specific biomass feedstock. Some researchers have applied this system on a single biomass feedstock [87-90]. Such a system appears promising if adapted for mixed feedstocks.

\section{Use of Specialized Feedstock Formulation and Processing Technologies}

Technical challenges arising from the combination of multiple feedstocks for bioethanol production can be overcome or reduced significantly if biomass forms with similar or different properties are combined using special feedstock formulation strategies. Blending or densification of related feedstocks can be done in order to combine the desirable characteristics of individual feedstocks. Aggregation of structurally different feedstocks can also be done by mixing pre-processed feedstocks in appropriate proportions in order to level out their differences. These strategies would produce a final feedstock with uniform and consistent characteristics that meet specific downstream processing requirements. This approach has the benefit of partially pretreating the feedstock and reducing the energy density of the biomass which also makes other logistic issues easier. For instance, some researchers [16] applied ionic liquid pretreatment on the flour (ground) form and pelleted mixtures of four different lignocellulosic feedstock in order to assess the effect of feedstock aggregation on sugar yield from ionic liquid pretreatment of the feedstock mixture. They obtained high sugar yields of up to $90 \%$ from both forms of the mixed feedstock within $24 \mathrm{~h}$; thus, further demonstrating the potential of feedstock blending in the processing of mixed feedstocks for lignocellulosic ethanol.

Additionally, very little or no modification of existing processing equipment and technologies (e.g. size reduction, pretreatment) would be required because the formulation strategies would have prepared the feedstock in a form that is easily handled by the existing machinery. Similar benefits are achievable if existing technologies are modified or new technologies are developed to be able to handle biomass mixtures which have varying characteristics. Such approaches have been demonstrated to be beneficial with mixed biomass in other applications $[31,72]$.

\section{Development and Use of Efficient Biocatalysts}

To overcome the challenge of catabolite repression or sequential sugar utilization arising from the presence of sugar mixtures in the hydrolysate of the MLB, microbial strains that do not exhibit diauxic growth or catabolite repression in the presence of pentose (C5) and hexose (C6) sugar mixtures should be used during fermentation [91]. This is because substrate mixtures do not always cause diauxic growth in all strains and some would even do better on such mixtures [78]. Also, microbial consortia whose members have preference for the different carbon sources in the hydrolysate may be used. Different microorganisms do not show the same response to different substrate mixtures and substrate mixtures that cause diauxy in one strain may not have the same effect in another strain [78].

Furthermore, the constraints against the fermenting microorganism in MLB ethanol production can be overcome by modifying the organisms to acquire properties that can make them cope with the nature of the hydrolysates. This can be achieved via measures such as genetic/metabolic engineering, evolutionary engineering or adaptation strategies. These may be done to confer characteristics on the organism such as ethanol tolerance, tolerating high sugar concentration, ability to utilize mixed substrates effectively and ability to withstand inhibitors. These options have been extensively reviewed elsewhere [92-94].

\section{Developing Processing Technologies that can Efficiently Handle Feedstocks with Varying Characteristics}

The cost and efficiency of MLB processing can be improved if appropriate technologies that can cope with the varying characteristics of the feedstock mixtures are used $[18,95,96]$. Such technologies are already available for gasification of mixed biomass [31]. It is possible that these kinds of technologies be introduced for bioethanol production. At the moment, different pretreatment technologies are suitable for certain kinds of feedstock only [97]. It would be interesting to have such pretreatments that could produce optimal sugar yields with diverse feedstock types for subsequent fermentation. 


\section{Conclusion}

The hope and success of replacing fossils with lignocellulosic biomass for the production of ethanol is challenged by high costs of feedstock supply logistics and complexities of the conversion technologies. The use of multiple feedstocks in the lignocellulosic biorefinery has potential for significant cost reductions and has thus gained increased attention lately. The technical feasibility of ethanol production from MLB has been demonstrated in few laboratory studies. It is possible that mixed feedstock use could generate significant cost reductions in terms of logistics but more empirical studies are required to establish this. This approach may also have positive environmental impacts which have to be shown/proven through life cycle assessments and energy balance investigations. Challenges related to processing technologies and peculiarities of MLB supply logistics could constrain the implementation of this system. However, the adoption of strategies targeted at feedstock supply logistics such as feedstock delivery in appropriate forms and proportions, strategic siting and decentralization of the biorefinery and mixed cropping, may mitigate the anticipated limitations. Likewise, technology-related strategies could facilitate the use of MLB in ethanol production. Such strategies include specialized feedstock formulations, use of optimum mixture ratios, developing flexible technologies that can handle varying feedstock characteristics, etc.

The outlook of ethanol from MLB is promising. A rapid increase in the amount of research in this area will likely be witnessed in the coming years. Researchers need to seek more revolutionary measures at ensuring the sustainability of the lignocellulosic ethanol industry.

Acknowledgments This work was supported by University of Malaya under grants RP011C-14SUS, RG048-11BIO, and PG114-2013B.

Open Access This article is distributed under the terms of the Creative Commons Attribution 4.0 International License (http:// creativecommons.org/licenses/by/4.0/), which permits unrestricted use, distribution, and reproduction in any medium, provided you give appropriate credit to the original author(s) and the source, provide a link to the Creative Commons license, and indicate if changes were made.

\section{References}

1. Luque R, Herrero-Davila L, Campelo JM, Clark JH, Hidalgo JM, Luna D, Marinas JM, Romero AA (2008) Biofuels: a technological perspective. Energy Environ Sci 1(5):542-564. doi:10.1039 /B807094F

2. Fink R, Medved S (2011) Global perspectives on first generation liquid biofuel production. Turk J Agric For 35(5):453-459. doi:10.3906/tar-1005-905

3. Demirbas A (2007) Progress and recent trends in biofuels. Prog Energy Combust Sci 33(1):1-18. doi:10.1016/j.pecs.2006.06.001
4. Balat M (2011) Production of bioethanol from lignocellulosic materials via the biochemical pathway: a review. Energy Convers Manag 52(2):858-875. doi:10.1016/j.enconman.2010.08.013

5. Celik MB (2008) Experimental determination of suitable ethanolgasoline blend rate at high compression ratio for gasoline engine. Appl Therm Eng 28(5-6):396-404. doi:10.1016/j. applthermaleng.2007.10.028

6. Lloyd P, Visagie E (2007) A comparison of gel fuels with alternative cooking fuels. J Energy South Afr 18(3):27

7. Wang J, Wasmus S, Savinell R (1995) Evaluation of ethanol, 1propanol, and 2-propanol in a direct oxidation polymer-electrolyte fuel cell a real-time mass spectrometry study. J Electrochem Soc 142(12):4218-4224. doi:10.1149/1.2048487

8. Rass-Hansen J, Falsig H, Jørgensen B, Christensen CH (2007) Bioethanol: fuel or feedstock? J Chem Technol Biotechnol 82: 329-333. doi:10.1002/jetb. 1665

9. Hayes DJ (2009) An examination of biorefining processes, catalysts and challenges. Catal Today 145(1):138-151. doi:10.1016/j. cattod.2008.04.017

10. Sims RE, Mabee W, Saddler JN, Taylor M (2010) An overview of second generation biofuel technologies. Bioresour Technol 101(6): 1570-1580. doi:10.1016/j.biortech.2009.11.046

11. Banerjee S, Mudliar S, Sen R, Giri B, Satpute D, Chakrabarti T, Pandey R (2010) Commercializing lignocellulosic bioethanol: technology bottlenecks and possible remedies. Biofuels Bioprod Biorefin 4(1):77-93. doi:10.1002/bbb.188

12. Solomon BD (2010) Biofuels and sustainability. Ann N Y Acad Sci 1185(1):119-134. doi:10.1111/j.1749-6632.2009.05279.x

13. Rentizelas A, Tatsiopoulos I, Tolis A (2009) An optimization model for multi-biomass tri-generation energy supply. Biomass Bioenergy 33(2):223-233. doi:10.1016/j.biombioe.2008.05.008

14. Sokhansanj S, Hess JR (2009) Biomass supply logistics and infrastructure. In: Mielenz JR (ed) Biofuels: methods and protocols, vol 581. Methods in molecular biology (Clifton, N.J.), vol 581. Humana Press, New York, pp. 1-25. doi:10.1007/978-1-60761214-8 1

15. Allen J, Browne M, Hunter A, Boyd J, Palmer H (1998) Logistics management and costs of biomass fuel supply. Int J Phys Distrib Logist Manag 28(6):463-477. doi:10.1108/09600039810245120

16. Shi J, Thompson VS, Yancey NA, Stavila V, Simmons BA, Singh S (2013) Impact of mixed feedstocks and feedstock densification on ionic liquid pretreatment efficiency. Biofuels 4(1):63-72. doi:10.4155/bfs. 12.82

17. Kenney KL, Smith WA, Gresham GL, Westover TL (2013) Understanding biomass feedstock variability. Biofuels 4(1):111127. doi: $10.4155 /$ bfs. 12.83

18. Williams CL, Westover TL, Emerson RM, Tumuluru JS, Li C (2015) Sources of biomass feedstock variability and the potential impact on biofuels production. Bioenergy Res 9(1):1-14. doi:10.1007/s12155-015-9694-y

19. Prakasham RS, Sathish T, Brahmaiah P, Rao CS, Rao RS, Hobbs PJ (2009) Biohydrogen production from renewable Agri-waste blend: optimization using mixer design. Int J Hydrog Energy 34:61436148. doi:10.1016/j.ijhydene.2009.06.016

20. Kim M-S, Lee D-Y (2010) Fermentative hydrogen production from tofu-processing waste and anaerobic digester sludge using microbial consortium. Bioresour Technol 101(1, Supplement):S48-S52. doi:10.1016/j.biortech.2009.03.040

21. Lehtomäki A, Huttunen S, Rintala JA (2007) Laboratory investigations on co-digestion of energy crops and crop residues with cow manure for methane production: effect of crop to manure ratio. Resour Conserv Recycl 51(3):591-609. doi:10.1016/j. resconrec.2006.11.004

22. Kalra M, Panwar J (1986) Anaerobic digestion of rice crop residues. Agr Wastes 17(4):263-269. doi:10.1016/0141-4607(86)90134-4 
23. Li J, Wei L, Duan Q, Hu G, Zhang G (2014) Semi-continuous anaerobic co-digestion of dairy manure with three crop residues for biogas production. Bioresour Technol 156:307-313. doi:10.1016/j.biortech.2014.01.064

24. Sangkharak K, Prasertsan P (2013) Municipal wastes treatment and production of polyhydroxyalkanoate by modified two-stage batch reactor. J Polym Environ 21(4):1009-1015. doi:10.1007/s10924013-0597-8

25. Shamala T, Vijayendra S, Joshi G (2012) Agro-industrial residues and starch for growth and co-production of polyhydroxyalkanoate copolymer and $\alpha$-amylase by Bacillus sp. CFR-67. Braz J Microbiol 43(3):1094-1102. doi:10.1590/S1517-838220120003000036

26. Azin M, Moravej R, Zareh D (2007) Production of xylanase by Trichoderma longibrachiatum on a mixture of wheat bran and wheat straw: optimization of culture condition by Taguchi method. Enzym Microb Technol 40(4):801-805. doi:10.1016/j. enzmictec.2006.06.013

27. Shamala TR, Sreekantiah KR (1986) Production of cellulases and d-xylanase by some selected fungal isolates. Enzym Microb Technol 8(3):178-182. doi:10.1016/0141-0229(86)90109-2

28. Nilsson D, Hansson P-A (2001) Influence of various machinery combinations, fuel proportions and storage capacities on costs for co-handling of straw and reed canary grass to district heating plants. Biomass Bioenergy 20(4):247-260. doi:10.1016/S0961-9534(00 00077-5

29. Freppaz D, Minciardi R, Robba M, Rovatti M, Sacile R, Taramasso A (2004) Optimizing forest biomass exploitation for energy supply at a regional level. Biomass Bioenergy 26(1):15-25. doi:10.1016 /S0961-9534(03)00079-5

30. Arantes MDC, Mendes LM, Rabelo GF, da Silva JRM, Mori FA, Barbosa AM (2008) Gasification of lignocellulosic materials for generation of electric energy. Cienc Florest 18(4):525-533

31. Faaij A, van Ree R, Waldheim L, Olsson E, Oudhuis A, van Wijk A, Daey-Ouwens C, Turkenburg W (1997) Gasification of biomass wastes and residues for electricity production. Biomass Bioenergy 12(6):387-407. doi:10.1016/S0961-9534(97)00010-X

32. Manzanares-Papayanopoulos E, Herrera-Velarde JR, ArriolaMedellín A, Alcaraz-Calderón AM, Altamirano-Bedolla JA, Fernández-Montiel M (2013) The co-gasification of coal-biomass mixtures for power generation: a comparative study for solid fuels available in Mexico. Energy Source Part A 36(1):104-111. doi:10.1080/15567036.2010.536817

33. Baxter L (2005) Biomass-coal co-combustion: opportunity for affordable renewable energy. Fuel 84(10):1295-1302. doi:10.1016/j. fuel.2004.09.023

34. Savolainen K (2003) Co-firing of biomass in coal-fired utility boilers. Appl Energy 74(3-4):369-381. doi:10.1016/s0306-2619 (02)00193-9

35. Erdei B, Barta Z, Sipos B, Réczey K, Galbe M, Zacchi G (2010) Ethanol production from mixtures of wheat straw and wheat meal. Biotechnol Biofuels 3(1):1-9. doi:10.1186/1754-6834-3-16

36. Martín C, Thomsen MH, Hauggaard-Nielsen H, BelindaThomsen A (2008) Wet oxidation pretreatment, enzymatic hydrolysis and simultaneous saccharification and fermentation of clover-ryegrass mixtures. Bioresour Technol 99(18):8777-8782. doi:10.1016/j. biortech.2008.04.039

37. Thomsen MH, Haugaard-Nielsen H (2008) Sustainable bioethanol production combining biorefinery principles using combined raw materials from wheat undersown with clover-grass. J Ind Microbiol Biotechnol 35(5):303-311. doi:10.1007/s10295-008-0334-9

38. Erdei B, Hancz D, Galbe M, Zacchi G (2013) SSF of steampretreated wheat straw with the addition of saccharified or fermented wheat meal in integrated bioethanol production. Biotechnol Biofuels 6(1):169

39. Tang Y, Zhao D, Cristhian C, Jiang J (2011) Simultaneous saccharification and cofermentation of lignocellulosic residues from commercial furfural production and corn kernels using different nutrient media. Biotechnol Biofuels 4(22):1-10. doi:10.1186/17546834-4-22

40. Brodeur-Campbell M, Klinger J, Shonnard D (2012) Feedstock mixture effects on sugar monomer recovery following dilute acid pretreatment and enzymatic hydrolysis. Bioresour Technol 116: 320-326. doi:10.1016/j.biortech.2012.03.090

41. Kim KH, Tucker M, Nguyen Q (2005) Conversion of bark-rich biomass mixture into fermentable sugar by two-stage dilute acidcatalyzed hydrolysis. Bioresour Technol 96(11):1249-1255. doi:10.1016/j.biortech.2004.10.017

42. Lim W-S, Lee J-W (2013) Effects of pretreatment factors on fermentable sugar production and enzymatic hydrolysis of mixed hardwood. Bioresour Technol 130:97-101. doi:10.1016/j. biortech.2012.11.122

43. Lynd L, Grethlein H (1987) Hydrolysis of dilute acid pretreated mixed hardwood and purified microcrystalline cellulose by cellfree broth from Clostridium thermocellum. Biotechnol Bioeng 29(1):92-100. doi:10.1002/bit.260290114

44. Mtui G, Nakamura Y (2005) Bioconversion of lignocellulosic waste from selected dumping sites in Dar es Salaam, Tanzania. Biodegradation 16(6):493-499. doi:10.1007/s10532-004-5826-3

45. Li A, Antizar-Ladislao B, Khraisheh M (2007) Bioconversion of municipal solid waste to glucose for bio-ethanol production. Bioprocess Biosyst Eng 30(3):189-196. doi:10.1007/s00449-0070114-3

46. Jensen JW, Felby C, Jørgensen H, Rønsch GØ, Nørholm ND (2010) Enzymatic processing of municipal solid waste. Waste Manag 30(12):2497-2503. doi:10.1016/j.wasman.2010.07.009

47. Moutta RDO, Silva M, Reis Corrales R, Santos Cerullo M, FerreiraLeitão V (2013) Comparative response and structural characterization of sugarcane bagasse, straw and bagasse-straw 1:1 mixtures subjected to hydrothermal pretreatment and enzymatic conversion. J Microb Biochem Technol S12:2-8. doi:10.4172/1948-5948.S12005

48. Moutta RDO, Ferreira-Leitão VS, Bon EPDS (2014) Enzymatic hydrolysis of sugarcane bagasse and straw mixtures pretreated with diluted acid. Biocatal Biotransfor 32(1):93-100. doi:10.3109 /10242422.2013.873795

49. Sherief AA, El-Tanash AB, Atia N (2010) Cellulase production by Aspergillus fumigatus grown on mixed substrate of rice straw and wheat bran. Res J Microbiol 5(3):199-211. doi:10.3923 jjm.2010.199.211

50. Kang S, Park Y, Lee J, Hong S, Kim S (2004) Production of cellulases and hemicellulases by Aspergillus niger KK2 from lignocellulosic biomass. Bioresour Technol 91(2):153-156. doi:10.1016 S0960-8524(03)00172-X

51. Qi B, Yaoa R, Yua Y, Chena Y (2007) Influence of different ratios of rice straw to wheat bran on production of cellulolytic enzymes by Trichoderma viride ZY-01 in solid state fermentation. Elec J Env Agricult Food Chem Title 6(9):2341-2349

52. Brandberg T, Karimi K, Taherzadeh MJ, Franzén CJ, Gustafsson L (2007) Continuous fermentation of wheat-supplemented lignocellulose hydrolysate with different types of cell retention. Biotechnol Bioeng 98(1):80-90. doi:10.1002/bit.21410

53. Jin Y, Yang L, Jameel H, H-m C, Phillips R (2013) Sodium sulfiteformaldehyde pretreatment of mixed hardwoods and its effect on enzymatic hydrolysis. Bioresour Technol 135:109-115. doi:10.1016 jj.biortech.2012.09.073

54. Sills DL, Gossett JM (2012) Using FTIR spectroscopy to model alkaline pretreatment and enzymatic saccharification of six lignocellulosic biomasses. Biotechnol Bioeng 109(4):894-903. doi:10.1002/bit.24376

55. Camassola M, Dillon A (2007) Production of cellulases and hemicellulases by Penicillium echinulatum grown on pretreated sugar 
cane bagasse and wheat bran in solid-state fermentation. J Appl Microbiol 103(6):2196-2204. doi:10.1111/j.1365-2672.2007.03458.x

56. Pal S, Banik SP, Khowala S (2013) Mustard stalk and straw: a new source for production of lignocellulolytic enzymes by the fungus Termitomyces clypeatus and as a substrate for saccharification. Ind Crop Prod 41:283-288. doi:10.1016/j.indcrop.2012.04.022

57. Oke MA, Annuar MSM, Simarani K (2016) Enhanced endoglucanase production by Bacillus aerius on mixed lignocellulosic substrates. Bioresources 11(3):5854-5869. doi:10.15376 /biores.11.3.5854-5869

58. Sills DL, Gossett JM (2012) Using FTIR to predict saccharification from enzymatic hydrolysis of alkali-pretreated biomasses. Biotechnol Bioeng 109(2):353-362. doi:10.1002/bit.23314

59. Jecu L (2000) Solid state fermentation of agricultural wastes for endoglucanase production. Ind Crop Prod 11(1):1-5. doi:10.1016 /S0926-6690(99)00022-9

60. Yang M, Kuittinen S, Zhang J, Vepsäläinen J, Keinänen M, Pappinen A (2015) Co-fermentation of hemicellulose and starch from barley straw and grain for efficient pentoses utilization in acetone-butanol-ethanol production. Bioresour Technol 179:128135. doi:10.1016/j.biortech.2014.12.005

61. Yang M, Kuittinen S, Zhang J, Keinänen M, Pappinen A (2013) Effect of dilute acid pretreatment on the conversion of barley straw with grains to fermentable sugars. Bioresour Technol 146:444 450 . doi:10.1016/j.biortech.2013.07.107

62. Pereira SC, Maehara L, Machado CM, Farinas CS (2015) 2G ethanol from the whole sugarcane lignocellulosic biomass. Biotechnol Biofuels 8:44. doi:10.1186/s13068-015-0224-0

63. Jensen J, Morinelly J, Aglan A, Mix A, Shonnard DR (2008) Kinetic characterization of biomass dilute sulfuric acid hydrolysis: mixtures of hardwoods, softwood, and switchgrass. AICHE J 54(6):1637-1645. doi:10.1002/aic.11467

64. Chin K, H'ng P, Wong L, Tey B, Paridah M (2011) Production of glucose from oil palm trunk and sawdust of rubberwood and mixed hardwood. Appl Energy 88(11):4222-4228. doi:10.1016/j. apenergy.2011.05.001

65. Lissens G, Klinke H, Verstraete W, Ahring B, Thomsen A (2004) Wet oxidation treatment of organic household waste enriched with wheat straw for simultaneous saccharification and fermentation into ethanol. Environ Technol 25(6):647-655. doi:10.1080 /09593330.2004.9619354

66. Nguyen QA, Keller FA, Tucker MP, Lombard CK, Jenkins BM, Yomogida DE, Tiangco VM (1999) Bioconversion of mixed solids waste to ethanol. Appl Biochem Biotechnol 77-79:455-471. doi:10.1385/ABAB:78:1-3:455

67. Ferreira P, da Silveira F, dos Santos R, Genier H, Diniz R, Ribeiro J Jr, Fietto L, Passos F, da Silveira W (2015) Optimizing ethanol production by thermotolerant Kluyveromyces marxianus CCT 7735 in a mixture of sugarcane bagasse and ricotta whey. Food Sci Biotechnol 24(4):1421-1427. doi:10.1007/s10068-015-0182-0

68. Elliston A, Wilson DR, Wellner N, Collins SR, Roberts IN, Waldron KW (2015) Effect of steam explosion on waste copier paper alone and in a mixed lignocellulosic substrate on saccharification and fermentation. Bioresour Technol 187:136-143. doi:10.1016/j.biortech.2015.03.089

69. Imamoglu E, Sukan FV (2014) The effects of single and combined cellulosic agrowaste substrates on bioethanol production. Fuel 134: 477-484. doi:10.1016/j.fuel.2014.05.087

70. Ji L, Yu H, Liu Z, Jiang J, Sun D (2015) Enhanced ethanol production with mixed lignocellulosic substrates from commercial furfural and cassava residues. Bioresources 10(1):1162-1173. doi:10.15376 /biores.10.1.1162-1173

71. Sultana A, Kumar A (2011) Optimal configuration and combination of multiple lignocellulosic biomass feedstocks delivery to a biorefinery. Bioresour Technol 102(21):9947-9956. doi:10.1016/j. biortech.2011.07.119
72. Rentizelas AA, Tolis AJ, Tatsiopoulos IP (2009) Logistics issues of biomass: the storage problem and the multi-biomass supply chain. Renew Sust Energ Rev 13(4):887-894. doi:10.1016/j. rser.2008.01.003

73. Murphy HT, O'Connell DA, Raison RJ, Warden AC, Booth TH, Herr A, Braid AL, Crawford DF, Hayward JA, Jovanovic T, McIvor JG, O'Connor MH, Poole ML, Prestwidge D, Raisbeck-Brown N, Rye L (2015) Biomass production for sustainable aviation fuels: a regional case study in Queensland. Renew Sust Energ Rev 44:738 750. doi:10.1016/j.rser.2015.01.012

74. Vera RM, Bura R, Gustafson R (2015) Synergistic effects of mixing hybrid poplar and wheat straw biomass for bioconversion processes. Biotechnol Biofuels 8(1):1-10. doi:10.1186/s13068-015-0414-9

75. Roopesh K, Ramachandran S, Nampoothiri KM, Szakacs G, Pandey A (2006) Comparison of phytase production on wheat bran and oilcakes in solid-state fermentation by Mucor racemosus. Bioresour Technol 97(3):506-511

76. Siddiqui Y, Meon S, Ismail R, Rahmani M (2009) Bio-potential of compost tea from agro-waste to suppress Choanephora cucurbitarum L. The causal pathogen of wet rot of okra. Biol Control 49(1):38-44. doi:10.1016/j.biocontrol.2008.11.008

77. Appels L, Lauwers J, Degrève J, Helsen L, Lievens B, Willems K, Van Impe J, Dewil R (2011) Anaerobic digestion in global bioenergy production: potential and research challenges. Renew Sust Energ Rev 15(9):4295-4301. doi:10.1016/j.rser.2011.07.121

78. Harder W, Dijkhuizen L, Postgate J (1982) Strategies of mixed substrate utilization in microorganisms [and discussion]. Philos Trans R Soc Lond B 297(1088):459-480. doi:10.1098/rstb.1982.0055

79. Kovárová-Kovar K, Egli T (1998) Growth kinetics of suspended microbial cells: from single-substrate-controlled growth to mixedsubstrate kinetics. Microbiol Mol Biol Rev 62(3):646-666

80. Gao D, Haarmeyer C, Balan V, Whitehead TA, Dale BE, Chundawat SP (2014) Lignin triggers irreversible cellulase loss during pretreated lignocellulosic biomass saccharification. Biotechnol Biofuels 7(1):175. doi:10.1186/s13068-014-0175-x

81. Rahikainen JL, Martin-Sampedro R, Heikkinen H, Rovio S, Marjamaa K, Tamminen T, Rojas OJ, Kruus K (2013) Inhibitory effect of lignin during cellulose bioconversion: the effect of lignin chemistry on non-productive enzyme adsorption. Bioresour Technol 133:270-278. doi:10.1016/j.biortech.2013.01.075

82. Bigelow M, Wyman CE (2002) Cellulase production on bagasse pretreated with hot water. Appl Biochem Biotechnol 98(1):921934. doi:10.1385/abab:98-100:1-9:921

83. Godin B, Lamaudière S, Agneessens R, Schmit T, Goffart JP, Stilmant D, Gerin PA, Delcarte J (2013) Chemical characteristics and biofuels potentials of various plant biomasses: influence of the harvesting date. J Sci Food Agric 93(13):3216-3224. doi:10.1002 /jsfa.6159

84. Bals B, Rogers C, Jin M, Balan V, Dale B (2010) Evaluation of ammonia fibre expansion (AFEX) pretreatment for enzymatic hydrolysis of switchgrass harvested in different seasons and locations. Biotechnol Biofuels 3(1):1-11

85. Eranki PL, Dale BE (2011) Comparative life cycle assessment of centralized and distributed biomass processing systems combined with mixed feedstock landscapes. GCB Bioenergy 3(6):427-438. doi:10.1111/j.1757-1707.2011.01096.x

86. Sathish T, Lakshmi GS, Rao CS, Brahmaiah P, Prakasham RS (2008) Mixture design as first step for improved glutaminase production in solid-state fermentation by isolated Bacillus sp. RSPGLU Lett Appl Microbiol 47(4):256-262. doi:10.1111/j.1472-765 X.2008.02413.x

87. Banerjee G, Car S, Scott-Craig JS, Borrusch MS, Aslam N, Walton JD (2010) Synthetic enzyme mixtures for biomass deconstruction: production and optimization of a core set. Biotechnol Bioeng 106(5):707-720. doi:10.1002/bit.22741 
88. Banerjee G, Car S, Scott-Craig JS, Borrusch MS, Bongers M, Walton JD (2010) Synthetic multi-component enzyme mixtures for deconstruction of lignocellulosic biomass. Bioresour Technol 101(23):9097-9105. doi:10.1016/j.biortech.2010.07.028

89. Banerjee G, Car S, Scott-Craig JS, Borrusch MS, Walton JD (2010) Rapid optimization of enzyme mixtures for deconstruction of diverse pretreatment/biomass feedstock combinations. Biotechnol Biofuels 3(1):22. doi:10.1186/1754-6834-3-22

90. Gao D, Chundawat SP, Krishnan C, Balan V, Dale BE (2010) Mixture optimization of six core glycosyl hydrolases for maximizing saccharification of ammonia fiber expansion (AFEX) pretreated corn Stover. Bioresour Technol 101(8):2770-2781. doi:10.1016/j. biortech.2009.10.056

91. Kim J-H, Block DE, Mills DA (2010) Simultaneous consumption of pentose and hexose sugars: an optimal microbial phenotype for efficient fermentation of lignocellulosic biomass. Appl Microbiol Biotechnol 88(5):1077-1085. doi:10.1007/s00253-010-2839-1

92. Taherzadeh MJ, Karimi K (2011) Fermentation inhibitors in ethanol processes and different strategies to reduce their effects. In: Pandey A, Larroche C, Ricke SC, Dussap C-G, Gnansounou E (eds) Biofuels, alternative feedstocks and conversion processes.
Academic, Amsterdam, pp. 287-311. doi:10.1016/B978-0-12385099-7.00012-7

93. Zaldivar J, Nielsen J, Olsson L (2001) Fuel ethanol production from lignocellulose: a challenge for metabolic engineering and process integration. Appl Microbiol Biotechnol 56(1-2):17-34. doi:10.1007/s002530100624

94. Dien B, Cotta M, Jeffries T (2003) Bacteria engineered for fuel ethanol production: current status. Appl Microbiol Biotechnol 63(3):258-266. doi:10.1007/s00253-003-1444-y

95. Shi J, George K, Sun N, He W, Li C, Stavila V, Keasling J, Simmons B, Lee T, Singh S (2015) Impact of pretreatment technologies on saccharification and isopentenol fermentation of mixed lignocellulosic feedstocks. Bioenergy Res 8(3):1004-1013. doi:10.1007/s12155-015-9588-Z

96. Morales-Vera R, Bura R, Gustafson R (2016) Handling heterogeneous hybrid poplar particle sizes for sugar production. Biomass Bioenergy 91:126-133. doi:10.1016/j.biombioe.2016.05.016

97. Alvira P, Tomás-Pejó E, Ballesteros M, Negro MJ (2010) Pretreatment technologies for an efficient bioethanol production process based on enzymatic hydrolysis: a review. Bioresour Technol 101(13):4851-4861. doi:10.1016/j.biortech.2009.11.093 